\title{
Morpho-anatomical adaptations of Potamogeton polygonus (Potamogetonaceae) to lotic and lentic environments
}

\author{
Adaptações morfo-anatômicas de Potamogeton polygonus aos ambientes lêntico e lótico
}

\author{
Makeli Garibotti Lusa ${ }^{1}$, Maria Regina Torres Boeger ${ }^{1}$, Maria Cecília de Chiara Moço ${ }^{2}$ \& Cleusa Bona ${ }^{1}$
}

\begin{abstract}
Aquatic macrophytes show great phenotypic plasticity and are able to occupy environments with different physicochemical conditions. The present study aimed to characterize morphology and anatomical structure of the pondweed, Potamogeton polygonus Cham. \& Schltdl., and to identify adaptive modifications of the plant in lotic and lentic environments. Sampling was carried out in Palmas and General Carneiro, Paraná state, southern Brazil. Ten individuals from each locality were collected. Morpho-anatomical characteristics of the roots, stems and leaves were measured. The anatomical structure was analyzed with light microscopy and scanning electron microscopy. Significant morphological and anatomical adaptive differences were observed between plants of the two environments.
\end{abstract}

Key words: anatomy, aquatic plant, morphology, phenotypic plasticity, Potamogeton.

\section{Resumo}

Plantas aquáticas apresentam grande plasticidade fenotípica, sendo capazes de ocupar ambientes com diferentes condições físico-químicas da água. O objetivo deste trabalho é caracterizar a morfologia e a estrutura anatômica de Potamogeton polygonus Cham. \& Schltdl., e identificar as alterações adaptativas da espécie em ambientes lêntico e lótico. As coletas foram realizadas nos municípios de Palmas e General Carneiro, Estado do Paraná, Brasil. Foram coletados dez indivíduos em cada localidade e realizadas mensurações de parâmetros morfológicos e anatômicos de raizes, caules e folhas. A estrutura anatômica foi analisada em microscopia fotônica e eletrônica de varredura. Foram constatadas modificações morfológicas e anatômicas de potencial papel adaptativo entre as plantas dos dois ambientes.

Palavras-chave: anatomia, morfologia, planta aquática, plasticidade fenotípica, Potamogeton.

\section{Introduction}

Aquatic plants are constantly subjected to a wide variety of environmental factors, which vary at continental scale (e.g. according to latitude and longitude) (Santamaría et al. 2003), as well as at local scale (e.g. light, temperature, salinity, flow velocity etc.) (Santamaría 2002). Many widely distributed aquatic species are able to respond plastically to diverse conditions (Santamaría 2002). Studies showed that even clonal populations of aquatic plants, which have low genetic variability, can exhibit compensatory plastic responses on environmental gradients (Grace 1993). The ability of an organism to change its morphology and physiology in response to environmental conditions is known as phenotypic plasticity (Via et al. 1995).
Rodrigues \& Irgang (2001) point out the large morphological variation among Brazilian species of Potamogeton L. Kaplan (2002) recorded the morphological plasticity of 41 experimentally cultivated species of Potamogeton from several parts of the world. The target species of most studies is $P$. pectinatus L. Due to its wide geographic distribution, plastic responses of this species have already been reported in relation to temperature (Spencer 1986), solar radiation ( Pilon \& Santamaría 2002b), nutrient availability in the sediment, wave turbulence (Idestam-Almquist \& Kautsky 1995) and latitude (Pilon \& Santamaría 2002a; Santamaría et al. 2003).

The species $P$. polygonus Cham. \& Schltdl. is widely distributed in South America, in lentic and lotic fresh waters (Rodrigues \& Irgang 2001). Rodrigues \& Irgang (2001) reported that this species

\footnotetext{
${ }^{1}$ Universidade Federal do Paraná, Depto. Botânica, Setor Ciências Biológicas, Campus 3 (Centro Politécnico), 81531-990, CP 19031, Curitiba, PR, Brazil. cleusabona@ufpr.br.

${ }^{2}$ Universidade Federal do Rio Grande do Sul, Instituto de Biociências, Depto. Botânica, 91509-900, Porto Alegre, RS, Brazil.
} 
exhibits large variation in leaf width, which may lead to error in taxonomic identification. However, there is no analysis of morphological and anatomical variations in this species. Wiegleb (1990) highlighted the importance of anatomical characters for the systematics of the genus, but only Alix \& Scribailo (2006) and Kaplan (2001) used this approach to distinguish species and hybrids.

The present study aimed to characterize the morphology and anatomical structure of the vegetative organs of $P$. polygonus and to identify the adaptive variations of this plant in lentic and lotic environments.

\section{Material and Methods}

Two study populations were chosen, which were subjected to different conditions of water velocity: 1) lotic environment - Arroio do Neno (262 21'06.2'’S ; 51 36'51.6'’ W), located at Lajeado Grande Farm, Palmas, state of Paraná, Iguaçú River Basin, a river composed mostly of water flowing over rocks, with deeper backwater areas; and 2) lentic environment-in dam 15, São PedroFarm, General Carneiro, state of Paraná(26²2'28.8'’S; 51²1'29.3'’W), an area with argillaceous sediment, shallower near the edges and deeper in the middle.

In each environment, water depth was measured at the deepest point and physicochemical parameters of the water were assessed at $10 \mathrm{~cm}$ below the surface. Temperature, oxygen level (in \% and $\mathrm{mg} / \mathrm{l}$ ) and $\mathrm{pH}$ were measured with a multi-parameter analyzer Consort C535. Water velocity was measured with Flow Probe FP101. Voucher material was deposited in the herbarium UPCB, Botany Department, Universidade Federal do Paraná, Curitiba, state of Paraná, southern Brazil, and assigned numbers UPCB 65092 (lotic environment) and UPCB 61311 (lentic environment).

For the quantitative morphology analysis, ten fully developed individuals were collected in each population. We measured total plant height and internode length of all individuals. Stem diameter was always measured along its longest axis, due to flattened shape. From the fifth apical node on, we removed five (5) leaves from each plant, which were then pressed and oven-dried at $60{ }^{\circ} \mathrm{C}$. For these leaves, we measured maximum values of leaf blade length and leaf blade width, as well as leaf area; we also calculated the arithmetic mean per individual for each variable. Measurements of leaf blade length and width were taken with a digital caliper $(0.01 \mathrm{~mm}$ resolution). Leaf area was calculated using digitalized images in the program Sigma Scan Pro (version 5.0, SPSS Inc., Chicago IL, USA).

For the quantitative anatomy analysis, we used samples from the same plants used for the morphological analysis. From each individual we collected samples of root (apex to the tenth node), stem and leaves (at the middle third of the leaf from the fifth node). Samples were fixed in FAA 50 (Johansen 1940), and preserved in $70 \%$ ethanol. Semi-permanent slides were assembled from freehand slices with razor blade, stained with toluidine blue and mounted in glycerinated gelatin (Roeser 1972; Berlyn \& Miksche 1976). Permanent slides were made from samples included in hydroxyethylmethacrylate resin, sectioned in a rotation microtome, stained with toluidine blue (O'Brien et al. 1965), and mounted in synthetic resin (Permount®). The lacunal areas of the stem and leaf mesophyll were measured from digital images of the abenchyma. Others anatomical parameters were measured: number of fiber bundles in the stem and in the leaf blade, and in the thickness of their cell wall fibers; the thickness of the leaf in the central region and mesophyll; the thickness of the cell wall of the root exodermis and the leaf epiderms. Microscopic analyses and photomicrographic records were made under photonic and stereoscopic microscopes (ZEISS Axiolab), with a digital camera attached.

For the analysis of leaf and stem surfaces and of the aerenchyma, samples of leaf and stem were observed under scanning electron microscopy. The samples were dehydrated in absolute ethanol and critical point dried with $\mathrm{CO}_{2}$, in the equipment BAL-TEC CPD 030, were adhered to metallic supports with adhesive copper tape, coated with gold in the equipment Balzers SCD 030, and analyzed under scanning electron microscopy Jeol 6360LV, at the Center for Scanning Electron Microscopy of Universidade Federal do Paraná.

In order to test for differences between specimens growing in lentic and lotic environments, data were submitted to an analysis of variance (ANOVA) and averages were submitted to a Student's t-test (significance level of 5\%) in MStat 5.2.

\section{Results}

\section{Study area}

Water abiotic parameters measured in each environment are presented in Table 1. The lentic environment is five times deeper than the lotic, which 
probably affects its velocity, which is 27 times lower. Electrical conductivity and dissolved salts were higher in the lentic environment, whereas dissolved oxygen was higher in the lotic environment. In both sites $\mathrm{pH}$ was similar, varying from 7.2 to 7.4 .

\section{Morphology}

Potamogeton polygonus plants are perennial and fixed-submersed herbs, with short internodes and linear, membranous, and parallel-nerved leaves with acuminate apex, truncate and sessile base, with stipule convolute and senescent. Plant morphology varied significantly between individuals of the lentic and lotic environments (Table 2). The plants from the lotic environment had lower values of leaf blade, leaf area, length between internodes and total plant height, but they had larger stem diameters. Plants from lotic and lentic environments did not differ significantly from each other in terms of leaf blade width.

\section{Anatomy}

Root - In the absorption zone, common epidermal cells have an outer periclinal wall that is convex and root hairs are positioned in front of the exodermal passage cells (Fig. 1a-b). At the end of the absorption zone, epidermal cells are eliminated leaving the exodermis exposed. The biseriate hypodermis is composed of one layer of exodermis and other layer of parenchyma cells (Fig. 1a). The exodermis has cells with thick walls and passage cells with thin walls (Fig. 1b). Wall thickness of the exodermal cells was greater in the lotic environment (Table 3). The aerenchyma resembles a radial lysigenous type; the lacunae are limited by radial septa (Fig. 1a). The inner region of the cortex is formed by approximately five layers of parenchyma cells with intercellular spaces, and internally by the endodermis (Fig. 1c). The endodermal cells, in the proximal region of the root, has secondary wall thickening in O-shape and distinguishable passage cells. The vascular cylinder is pentarch, the pericycle is discontinuous and the sieve tube elements are in direct contact with the endodermis (Fig. 1c). No structural difference in the vascular cylinder was observed between plants of the two environments.

Stem - The transverse section of this organ is elliptical. The epidermis exhibits square-shaped cells (Fig. 1d) with chloroplasts and a thickened outer periclinal wall, with occasional epicuticular striations. The cortex is composed of a subepidermal layer of parenchyma cells with chloroplasts, interspersed by fiber bundles and aerenchyma, with the cells arranged in a honeycomb (Fig. 1d). The aerenchyma lacunae are divided transversally by uniseriate diaphragms formed by arm-shaped cells (Fig. 1e-g). The cells that limit the air lacunae and those that compose the diaphragm have chloroplasts. No difference in aerenchyma pattern or percentage of lacunal area was recorded between plants from the two environments (Table 3). Fiber bundles also appear scattered among the parenchyma cells of the aerenchyma. There was no difference in the total number of fiber bundles, but the walls of these fibers were thicker in the lotic environment (Table 3). The walls of endodermal cells, in the younger portions of the stem, have only Casparian strips, but in the completely developed internodes they undergo thickening and lignification. The vascular cylinder is oblong in transverse section, with four to six vascular bundles: two larger in the center and two smaller on each side, without pith formation (Fig. 1h). Both central and lateral bundles can exhibit fusion. Vascular bundles exhibit large lacunae of protoxylem, large phloem sieve elements and are partially surrounded by fibers. The vascular cylinder structure is similar in both environments.

Leaf - The epidermis is uniseriate and chlorophyllous, and in the lotic environment the outer periclinal walls are thicker (Table 3; Fig. 2a). In frontal view, the leaf cells are rectangular in the

Table 1 - Abiotic parameters of lotic and lentic environments where Potamogeton polygonus was sampled. Values refer to $\mathrm{pH}$, water velocity (V), oxygen level (in \% and $\mathrm{mg} / \mathrm{L}$ ), electricity (E), conductivity (C) and total salts dissolved (TSD).

\begin{tabular}{lcccccccc}
\hline Environment & $\begin{array}{c}\text { depth } \\
(\mathbf{m})\end{array}$ & $\mathbf{p H}$ & $\mathbf{V}$ & $\mathbf{O}_{\mathbf{2}}$ & $\begin{array}{c}\mathbf{O}_{\mathbf{2}} \\
(\mathbf{m g} / \mathbf{L})\end{array}$ & $\begin{array}{c}\mathbf{E} \\
(\mathbf{m v})\end{array}$ & $\begin{array}{c}\mathbf{C} \\
(\mathbf{i} \mathbf{S})\end{array}$ & $\begin{array}{c}\text { TSD } \\
(\mathbf{m g} / \mathbf{L})\end{array}$ \\
\hline Lentic & 4 & 7.4 & 0 & 86.5 & 8.5 & -16 & 31 & 16.7 \\
Lotic & 0.8 & 7.2 & 27 & 95.5 & 9.25 & 14 & 23.3 & 12.5 \\
\hline
\end{tabular}



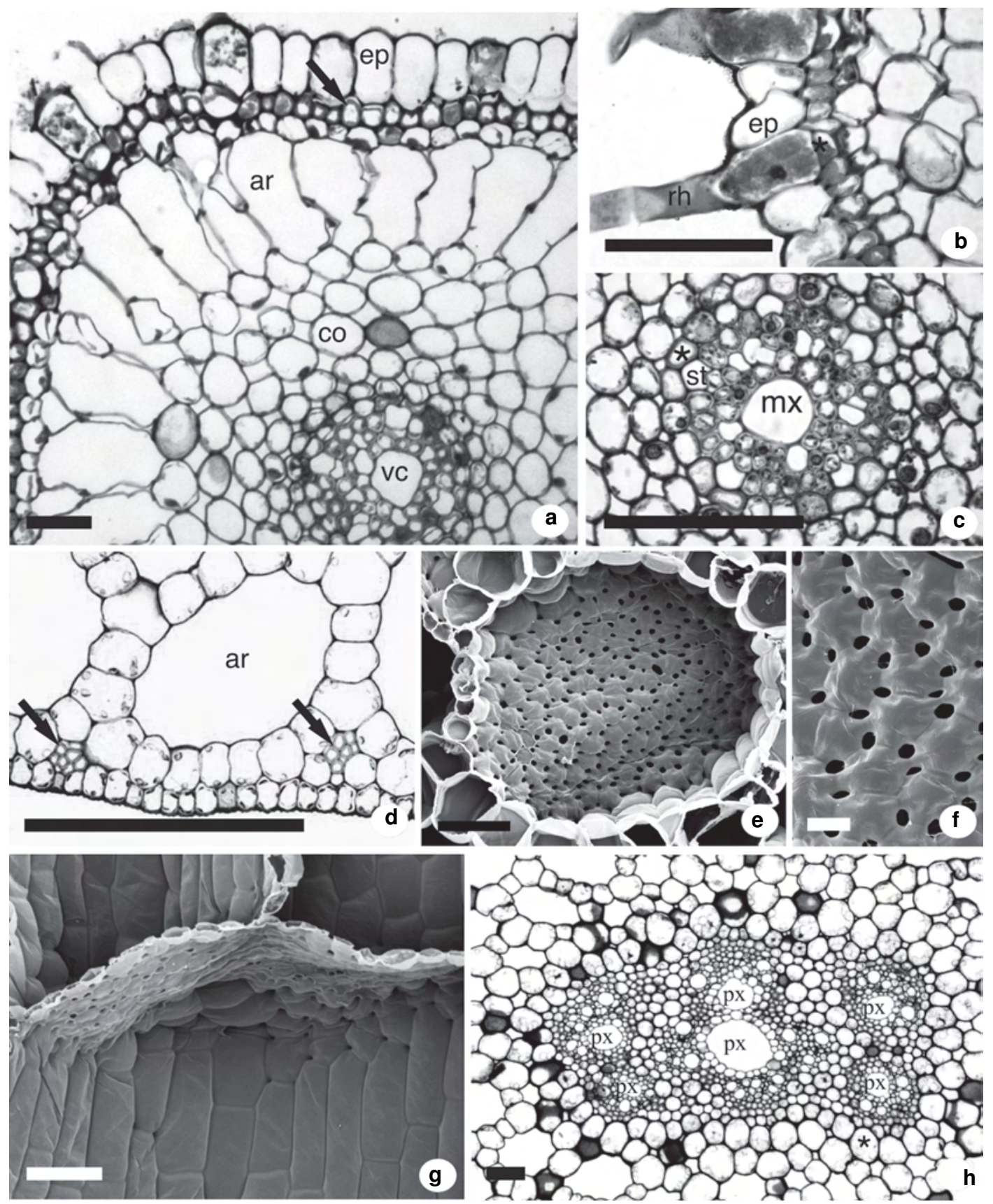

Figures 1a-h - Root and stem of Potamogeton polygonus. a. Transverse section of the root, showing the epidermis (ep), exodermis (arrow), aerenchyma (ar), inner cortex (co) and vascular cylinder (vc). b. Detail of the epidermis (ep) with root hairs (rh) and exodermis with passage cells $(*)$. c. Transverse section of the root with pentarch pattern, evidencing a central metaxylem element and a sieve tube element (st) in direct contact with the endodermis $(*)$. d. Transverse section of the stem, showing the epidermis with chloroplasts, air lacunar and subepidermal fiber bundles (arrow). e. Diaphragm of stem aerenchyma, in frontal view. f. Detail of diaphragm cells, from Figure e. g. Diaphragm of stem aerenchyma, in longitudinal view. h. Transverse section of the stem, showing the organization of the six vascular bundles and protoxylem lacunae. Figures a, b, c, d and h are photomicrographs in light microscope, stained with toluidine blue. Figures e, $f$ and $g$ are electron micrographs in scanning electron microscopy. Scale bars $=50 \mu \mathrm{m}$ (except for Figure $\mathrm{f}$, scale bar $=10 \mu \mathrm{m}$ ). 
Table 2 - Anatomical characteristics of Potamogeton polygonus root, stem and leaf in lotic and lentic environments. Data are given as mean \pm standard deviation $(n=10)$. Letters stand for significant differences between specimens in the two environments (Student's t test, $\mathrm{P}<0.05$ ).

\begin{tabular}{lcc}
\hline Characteristics & Lotic environment & Lentic environment \\
\hline Total plant heigth $(\mathrm{cm})$ & $37.29 \pm 10.51^{\mathrm{a}}$ & $48.2 \pm 11.54^{\mathrm{b}}$ \\
Internode length $(\mathrm{cm})$ & $1.45 \pm 0.44^{\mathrm{a}}$ & $2.56 \pm 0.87^{\mathrm{b}}$ \\
Leaf blade length $(\mathrm{cm})$ & $8.41 \pm 1.82^{\mathrm{a}}$ & $9.39 \pm 1.70^{\mathrm{b}}$ \\
Leaf blade width $(\mathrm{cm})$ & $0.35 \pm 0.06^{\mathrm{a}}$ & $0.36 \pm 0.06^{\mathrm{a}}$ \\
Leaf area $\left(\mathrm{cm}^{2}\right)$ & $2.23 \pm 0.66^{\mathrm{a}}$ & $2.49 \pm 0.89^{\mathrm{b}}$ \\
Stem diameter $(\mathrm{cm})$ & $0.39 \pm 0.06^{\mathrm{a}}$ & $0.33 \pm 0.04^{\mathrm{b}}$ \\
\hline
\end{tabular}

Table 3 - Morphological characteristics of Potamogeton polygonus root, stem and leaf in lotic and lentic environments. Data are presented as mean \pm standard deviation $(n=10)$. Letters stand for significant differences between specimens in the two environments (Student's t test, $\mathrm{p}<0.05$ ).

\begin{tabular}{lcc}
\hline Characteristics & Lotic environment & Lentic environment \\
\hline Exodermal wall thickness $(\mu \mathrm{m})$ & $0.92 \pm 0.16^{\mathrm{a}}$ & $0.40 \pm 0.16^{\mathrm{b}}$ \\
Lacunal area of the stem $(\%)$ & $49.03 \pm 0.05^{\mathrm{a}}$ & $44.92 \pm 0.07^{\mathrm{a}}$ \\
Number of fiber bundles in the stem & $32.5 \pm 2.59^{\mathrm{a}}$ & $29.8 \pm 3.06^{\mathrm{a}}$ \\
Wall thickness of the stem fibers $(\mu \mathrm{m})$ & $1.59 \pm 0.26^{\mathrm{a}}$ & $1.08 \pm 0.22^{\mathrm{b}}$ \\
Wall thickness of the leaf epidermis $(\mu \mathrm{m})$ & $1.37 \pm 0.21^{\mathrm{a}}$ & $0.83 \pm 0.06^{\mathrm{b}}$ \\
Thickness of the leaf central region $(\mu \mathrm{m})$ & $153.49 \pm 17.9^{\mathrm{a}}$ & $124.5 \pm 15.1^{\mathrm{b}}$ \\
Thickness of the leaf mesophyll $(\mu \mathrm{m})$ & $41.5 \pm 3.3^{\mathrm{a}}$ & $30.71 \pm 4^{\mathrm{a}}$ \\
Lacunal area of the leaf mesophyll $(\%)$ & $35.29 \pm 0.08^{\mathrm{a}}$ & $40.40 \pm 0.07^{\mathrm{b}}$ \\
Number of fiber bundles in the leaf blade & $44.4 \pm 4.87^{\mathrm{a}}$ & $28.6 \pm 0.89^{\mathrm{b}}$ \\
Wall thickness of the leaf fibers $(\mu \mathrm{m})$ & $1.48 \pm 0.1^{\mathrm{a}}$ & $0.93 \pm 0.04^{\mathrm{b}}$ \\
\hline
\end{tabular}

lentic environment (Fig. 2b), and quadrangular in the lotic environment (Fig. 2c). The mesophyll is similar in both environments, formed by aerenchyma in the central region (Fig. 2a) and by a single layer of chlorophyllous parenchyma in the rest of the blade leaf (Fig. 2e-g). The leaf aerenchyma also exhibits diaphragms composed of arm-shaped chlorophyllous cells, similar to those found in the stem. The aerenchyma in the leaves of the lentic environment have a lacunal area proportionately larger than the one in leaves of the lotic environment (Table 3). In the leaf blade, fiber bundles and vascular bundles are alternated, and fiber bundles predominate (fig. 2d-e). On each border, there is a large fiber bundle at subepidermal position (Fig. 2f-g). The vascular bundles are collateral and have a fiber cap in the periphery of the phloem and xylem (fig. 2a). The vascular bundle of the central region is more developed in the lotic environment, which results in greater leaf thickness in this environment (Table 3).

\section{Discussion}

Potamogeton polygonus exhibits several characteristics that differentiate individuals from lotic and lentic environments, both in terms of external morphology and anatomical structure. Plants from the lotic environment are shorter and have smaller leaf area, but larger stem diameter and leaf blade thickness. Similar morphological adaptations were recorded in several species subjected to hydrodynamic stress (IdestamAlmquist \& Kautsky 1995; Schutten \& Davy 2000; Gantes \& Caro 2001; Puijalon \& Bornette 2004; Puijalon et al. 2005). Hydrodynamic forces can lead to convergence, due to plasticity or selection, which allows better performance in each environment. Reduced size and greater stem thickness can decrease risk of breakage and uprooting (IdestamAlmquist \& Kautsky 1995; Schutten \& Davy 2000) and decrease resistance to water flow (Boeger \& Poulson 2003). In P. polygonus, we also recorded a 

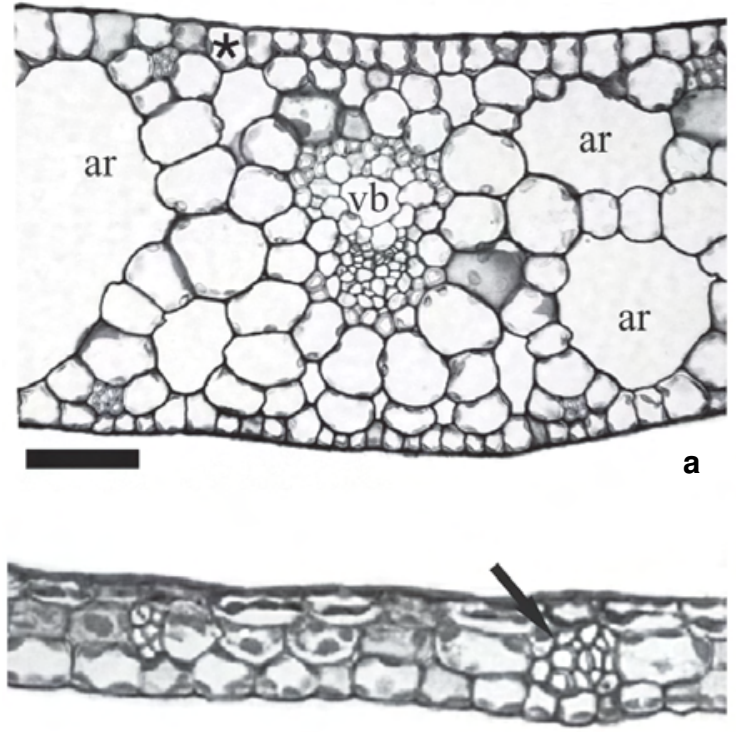

d

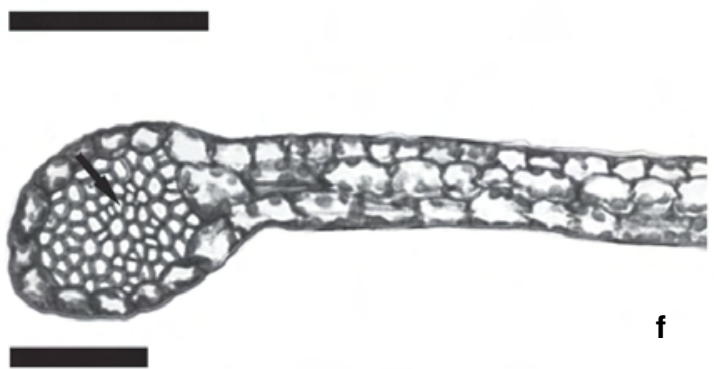

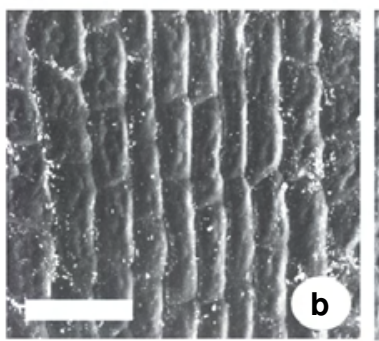
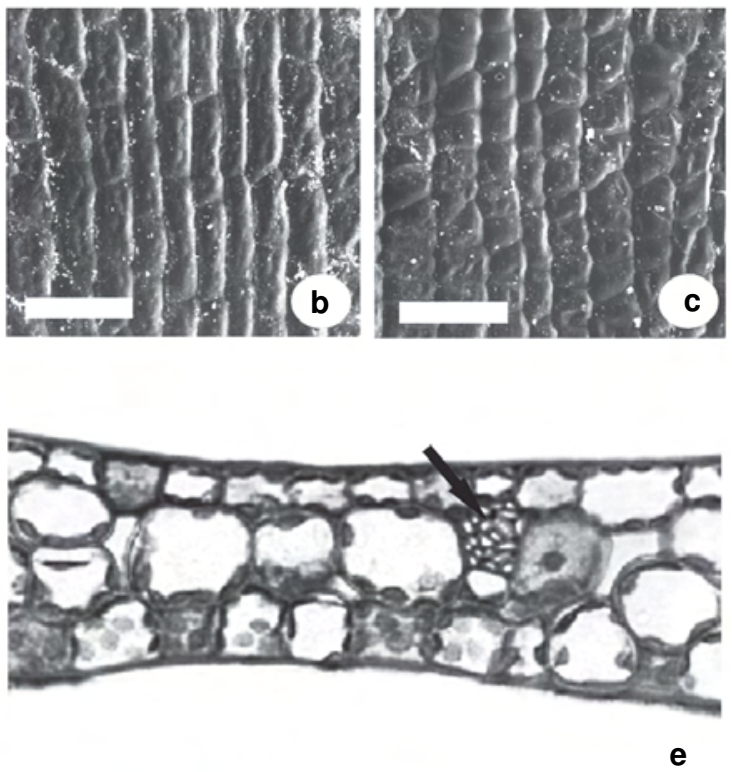

e

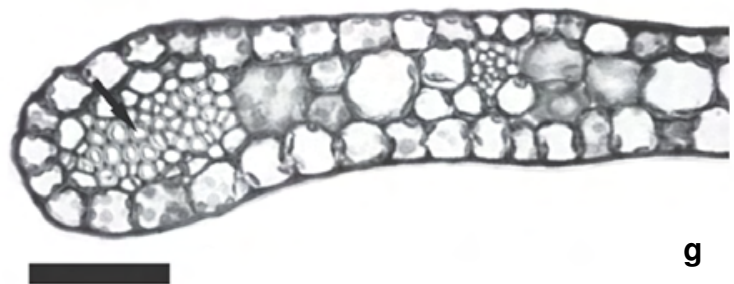

Figures 2a-g - Leaf of Potamogeton polygonus. a. Transverse section of the leaf blade, in the central region, showing epidermis (*), aerenchyma (ar) and vascular bundle (vb). b. Leaf blade surface (lentic environment), showing the rectangular shape of the epidermal cell. c. Leaf blade surface (lotic environment), showing the quadrangular shape of the epidermal cell. $d$. Transverse section of the leafblade (lentic environment), showing fiber bundles in the mesophyll (arrow). e. Transverse section of the leaf blade (lotic environment), showing fiber bundles in the mesophyll (arrow). f. Transverse section of the leaf blade (lentic environment), showing the fiber bundles in the leaf edge. g. Transverse section of the leafblade ( lotic environment), showing the fiber bundles in the leaf edge. Figures a, d, e, fand g are photomicrographs in light microscopy, stained with toluidine blue. Figures $\mathrm{b}$ and $\mathrm{c}$ are electron micrographs in scanning electron microscopy. Scale bar $=50 \mathrm{~mm}$.

higher number of fiber bundles in the leaves, that can be interpreted as an adaptive response that increases resistance to hydrodynamic forces.

The aforementioned studies relate morphological adaptations only to water velocity, but the addition of information on light availability would be more elucidating. Puijalon \& Bornette (2004) suggested that plants that grow in environments with higher water velocity usually exhibit horizontal branches aligned with the stream. These authors explain that this inclination reduces resistance, but do not mention that it also increases the area exposed to solar radiation. Thus, individuals of $P$. polygonus from lotic environments would not need to invest so much in apical growth and leaf area compared with those from lentic environments, as observed in the present study. In contrast, individuals from lentic environments are rooted in deeper substrates, and are potentially subjected to other factors that could reduce light availability, such as periphyton growth and sedimentation of suspended particles on leaves. Studies show that there are similarities between the responses of plants subjected to shade and submersion, since blade water depth acts as a light filter (Boeger \& Poulson 2003; Mommer et 
al. 2005). Spencer (1986) also showed that in $P$. pectinatus stem elongation rate is negatively related to solar radiation.

Aquatic plants also face hypoxia and exhibit different adaptive strategies to survive this stress. Species with emergent or floating leaves, which have fixed roots in anoxic sediments, depend on the internal transport of oxygen from leaves to roots through the system of air lacunae, whereas submersed species obtain these gases by diffusion (Rascio 2002). Leaves of submersed species can be entire, windowed or dissected (Sculthorpe 1967). Species that exhibit entire leaves are frequently very thin and more or less translucent, and do not have developed aerenchyma. In P. polygonus, the marginal regions of the leaf blade have only three layers of cells and the aerenchyma occurs only in the thicker central region. The lower proportion of leaf lacunal area found in leaves from the lotic environment in the present study can be related to higher oxygenation caused by turbulence in this environment.

Several authors studied the origin and classification of the aerenchyma architecture in root and stem of aquatic plants (Seago et al. 2005; Evans 2003; Jung et al. 2008). In the root of terrestrial flood-tolerant plants, the aerenchyma is frequently of lysigenous origin: some cells die and disappear, forming air spaces (Evans 2003). However, in most aquatic plants, the formation of the lacunae of the lysigenous aerenchyma in the root occurs with the collapse of cellular content, but with maintenance of the cell walls (Seago et al. 2005; Jung et al. 2008). In the studied species, rows of radial cells collapse maintaining their cell walls intact, and form an aerenchyma of the radial lysigenous type, according to the classification of Seago et al. (2005). It is believed that in $P$. polygonus these walls have an important role in maintaining the shape and increasing the tensional force of the organ, likewise the diaphragms in stem and leaves. In this species, the origin and architecture of the root aerenchyma differ from that recorded of the stem and leaves. In the stem, the aerenchyma is arranged as a honeycomb. According to Seago et al. (2005), when this type of aerenchyma occurs in the roots, it originated from the oblique division and expansion of the cells that surrounded the air lacunae, and is denominated expansigenous. However, Jung et al. (2008) state that in stems this type of aerenchyma does not necessarily have homologous origin with the root.

Diaphragms are widely found in stems and leaves of aquatic plants, especially in monocotyledons
(Sculthorpe 1967). They can be formed by a single cell layer (Bona \& Alquini 1995 b; Evans 2003), by two or, occasionally, by three cell layers (Sculthorpe 1967). Sculthorpe (1967) reported that in Potamogeton each diaphragm is formed by one or occasionally two to three cell layers. Diaphragms with one cell layer were also recorded in the leaves and stems of $P$. illinoensis Morong and P. gayi A. Benn. (Rodrigues 2006). Diaphragms present in the aerenchyma, in addition to helping support it, seem to have other functions, such as the isolation of damaged internodes, preventing water from invading and damaging other parts of the plant (Sculthorpe 1967; Soukup et al. 2000).

Addition to hypoxia, another limiting factor of submersed plants is the low solubility of carbon dioxide. However, to overcome this condition, many submersed plants, including Potamogeton species, exhibit morphological and physiological adaptations to increase the input gas capacity (Sand-Jensen \& Gordon 1984; Madsen \& SandJensen 1991; Van den Berg et al. 2002; Rascio 2002). For $P$. polygonus, diaphragms can also be important in the enlargement of areas for $\mathrm{CO}_{2}$ fixation, because they have chloroplasts, corroborating what was previously suggested by Scremin-Dias et al. (1999). Diaphragms with chlorophyllous cells were also recorded in leaves and stems of $P$. illinoensis and $P$. gayi (Rodrigues 2006).

Many submersed species use the bicarbonate ion $\left(\mathrm{HCO}_{3}^{-}\right)$as an inorganic carbon source (SandJensen \& Gordon 1984; Madsen \& Sand-Jensen 1991; Van den Berg et al. 2002; Rascio 2002). For the input of $\mathrm{HCO}_{3}{ }^{-}$in the cell, a conversion of $\mathrm{HCO}_{3}-$ into $\mathrm{CO}_{2}$ must occur in the cell wall or in the presence of a carrier protein in the plasmalemma. For this reason, Rascio (2002) emphasizes that in species in which this route for the use of $\mathrm{HCO}_{3}^{-}$ occurs, including species of Potamogeton, there is a thickening of the outer periclinal wall of the epidermal cells, with projections towards the interior of the cell, increasing the plasmalemma area. The details of the projections of the walls of epidermal-cells walls can only be observed in transmission electron microscopy, but the thickening of the wall could be observed in the epidermal cells of the leaf and stem of $P$. polygonus.

The stem vascular system of aquatic angiosperms may seem to be reduced compared to terrestrial species, even a fusion of vascular bundles can occur in the center, resembling the stele of roots (Sculthorpe 1967). Schenck (1886 apud Sculthorpe 1967) states that this reduction in the stem vascular 
system represents an important mechanical adaptation. In the genus Potamogeton several stages of fusion and reduction of vascular bundles are observed, characteristics that are important for the systematics of the group (Sculthorpe 1967; Wiegleb 1990; Kaplan 2001). Wiegleb (1990) describes four types of stele: the proto type, with four (rarely three) median bundles and three (5-6) lateral bundles, as recorded in Potamogeton pulcher Tuckerman; the type with 8 bundles, in which three median bundles fuse, e.g. P. natans Thunb; the oblong type, in which the stele is not lobed and the bundles are grouped into three groups, e.g. Potamogeton lucens L.; and the type with four bundles, recorded by the author only in Australian species of the complex $P$. cheesemanii A. Bennett. The species $P$. pectinatus was not cited in the study of Wiegleb (1990), but Sculthorpe (1967) emphasizes that in this species a more or less homogeneous phloem zone occurs, surrounding a central axial lacuna. Kaplan (2001) used characteristics of the stem's stele to distinguish the hybrid $P$. $x$ fluitans Roth from its parietals $P$. natans and $P$. lucens. The pattern found in $P$. polygonus is consistent with the description of the oblong type by Wiegleb (1990).

In many Potamogeton species cortical interlacunar and subepidermal vascular bundles occur (Sculthorpe 1967; Kaplan 2001; Alix \& Scribailo 2006). These bundles do not occur in P.crispus L. (Alix \& Scribailo 2006) nor in P. polygonus.

In roots of aquatic monocotyledons the polyarch stele also exhibits a reduction in the number of arches and even a complete absence of medullar parenchyma. Sauvageau (1894 apud Sculthorpe 1967) studied the progressive reduction of this system in roots of Potamogeton and found that in $P$. natans and $P$. pectinatus the stele is pentarch, as also recorded for $P$. polygonus in the present study.

The reduction of the root vascular system does not indicate, necessarily, a reduction in the capacity of absorption of water and solutes. The presence of root hairs located in front of exodermal passage cells, recorded in $P$. polygonus, indicates that there is a potential regulation of the lateral flow of water and ions in roots. It has been shown that in most aquatic species the exodermis has similar functions similar to the endodermis (Esnault et al. 1994; Kamula et al. 1995; Seago et al. 2000; Enstone et al. 2003; Soukup et al. 2007). The importance of the sediment as a source of essential minerals for rooted submersed aquatic plants has already been demonstrated in previous studies with Ranunculus trichophyllus Chaix (Ranunculaceae) (Dalla Vecchia et al. 1999) and other species of Potamogeton (Chambers et al. 1989; IdestamAlmquist \& Kautsky 1995).

The presence of Caspary strips in endodermal cells of stem and leaf of $P$. polygonus is common also in other aquatic plants (Sculthorpe 1967). In aquatic plants, this layer may have the function of ionic selectivity, but can also be a barrier to the exit of gases from the vascular cylinder and to the entrance of pathogens (Esnault et al. 1994; DallaVecchia et al. 1999; Enstone et al. 2003). Frank \& Hodgson (1964) investigated the absorption of herbicides marked with ${ }^{14} \mathrm{C}$, in different parts of specimens of $P$. pectinatus, and confirmed the absorption capacity of leaves in addition to roots.

A neglected characteristic, both for aerenchymatous and non-aerenchymatous roots of aquatic plants, is the mechanical function of wall thickening in cortex cells, in addition to the endodermis and exodermis. In the case of Caltha palustris L.(Ranunculaceae), the cortex has no aerenchyma and the cells of the inner cortex have slight wall thickening (Seago et al. 2000). In Nymphaea odorata Aiton (Nympheaceae), lignified sclereids, close to the endodermis, provide the mechanical support (Seago et al. 2000). In the roots of $P$. polygonus the mechanical layers, which exhibit wall thickening, are the endodermis and exodermis. The greater wall thickening in $P$. polygonus in lotic environments is consistent with its association with mechanical resistance.

\section{Ackowledgements}

$\mathrm{CNPq}$ (Brazilian Research Council) funded this study (Edital Universal CNPq n ${ }^{\circ}$ 019/2004) and granted productivity fellowships to Dr. Cleusa Bona and Dr. Maria Regina Boeger; Instituto Ecoplan and Fundação Pizzatto provided logistic support during fieldwork.

\section{References}

Alix, M.S. \& Scribailo, R.W. 2006. First report of Potamogeton $\mathrm{x}$ undulatus $(P$. crispus $\mathrm{x} P$. praelongus, Potamogetonaceae) in North America, with notes on morphology and stem anatomy. Rhodora 108: 329-346.

Berlyn, G.P. \& Miksche, J.P. 1976. Botanical microtechnique and cytochemistry. The Iowa State Press, Ames. 326p.

Boeger, M.R.T. \& Poulson M. E. 2003. Morphological adaptations and photosynthetic rates of amphibious 
Veronica anagallis-aquatica L. (Scrophulariaceae) under different flow regimes. Aquatic Botany 75: 123-135.

Bona, C. \& Alquini, Y. 1995a. Anatomia foliar de Hydrocleis nymphoides (Humb. \& Bomp. ex Willd) Buchenau (Limnocharitaceae). Arquivos de Biologia e Tecnologia 38: 869-877.

Bona, C. \& Alquini, Y. 1995b. Alguns aspectos estruturais da folha de Limnobium laevigatum (Humb. \& Bompl. Ex. Willd) Heine (Hydrocharitaceae). Arquivo de Biologia e Tecnologia 38: 1045-1052.

Chambers, P.A.; Prepas, E.E.; Bothwell, M.L. \& Hamilton, H.R. 1989. Roots versus shoots in nutrient uptake by aquatic macrophytes in flowering waters. Canadian Journal of Fish and Aquatic Science 46: 435-439.

Dalla-Vecchia, F.; Cuccato, F.; Rocca, N.La; Larcher, W. \& Rascio, N. 1999. Endodermis-like sheaths in the submerged freshwater macrophyte Ranunculus trichophyllus Chaix. Annals of Botany 83: 93-97.

Enstone, D.E.; Peterson, C.A. \& Ma, F. 2003. Root endodermis and exodermis: structure, function, and responses to the environment. Journal of Plant Growth Regulation 21: 335-351.

Esnault, A.L.; Masuhara G. \& McGee P.A. 1994. Involvement of exodermal passage cells in mycorrhizal infection of some orchids. Mycological Research 98: 672-676.

Evans, D.E. 2003. Aerenchyma formation. New Phytologist 161: 35-49.

Frank, P.A. \& Hodgson, R.H. 1964. A technique for studying absorption and translocation in submersed plants. Weeds 12: 80-82.

Gantes, H.P. \& Caro, A.S. 2001. Environmental heterogeneity and spatial distribution of macrophytes in plain streams. Aquatic Botany 70: 225-236.

Grace, J.B. 1993. The adaptave significance of clonal reproduction in angiosperms: a perspective. Aquatic Botany 44: 159-180.

Idestam-Almquist, J. \& Kautsky, L. 1995. Plastic responses in morphology of Potamogeton pectinatus $\mathrm{L}$. to sediment and above-sediment conditions at two sites in the northern Baltic proper. Aquatic Botany. 52: 205-216.

Johansen, D.A. 1940. Plant microtechnique. McGraw Hill Book, New York. 523p.

Jung, J.; Lee, S.C. \& Choi, H. 2008. Anatomical patterns of aerenchyma in aquatic and wetland plants. Journal of Plant Biology 51: 428-439.

Kaplan, Z. 2001. Potamogeton $\mathrm{x}$ fluidans (P. natans $\mathrm{x} P$. lucens) in the Czech Republic I. Morphology and anatomy. Preslia 73: 333-340.

Kaplan, Z. 2002. Phenotypic plasticity in Potamogeton (Potamogetonaceae). Folia Geobotanica 37: 141-170.
Madsen, T.V. \& Sand-Jensen, K. 1991. Photosynthetic carbon assimilation in aquatic macrophytes. Aquatic Botany 41: 5-40.

Mommer, L.; Kroon, H.; Pierik, R.; Bögemann, G.M. \& Visser, E.J.W. 2005. A functional comparison of acclimation to shade and submergence in two terrestrial plant species. New Phytologist 167: 197-206.

O’Brien, T.P.; Feder, N. \& McCully, M.E. 1965. Polychromatic staining of plant cell walls by toluidine blue O. Protoplasma 59: 368-373.

Pilon, J. \& Santamaría, L. 2002a. Clonal variation in the thermal response of the submerged aquatic macrophyte Potamogeton pectinatus. Journal of Ecology 90: 141-152.

Pilon, J. \& Santamaría, L. 2002b. Clonal variation in morphological and physiological responses to irradiance and photoperiod for the aquatic angiosperm Potamogeton pectinatus. Journal of Ecology 90: 859-870.

Puijalon, S. \& Bornette, G. 2004. Morphological variation of two taxonomically distant plant species along a natural flow velocity gradient. New Phytologist 163 : 651-660.

Puijalon, S.; Bornette, G. \& Sagnes, P. 2005. Adaptations to increasing hydraulic stress: morphology, hydrodynamics and fitness of two higher aquatic plant species. Journal of Experimental Botany 56: 777-786.

Rascio, N. 2002. The underwater life of secondarily aquatic plants: some problems and solutions. Critical Reviews in Plant Sciences 21: 401-427.

Rodrigues, R.S. \& Irgang, B.E. 2001. Potamogetonaceae Dumort. no Rio Grande do Sul, Brasil. Iheringia, Serie Botânica 56: 3-49.

Rodrigues, S. 2006. O gênero Potamogeton L. em rios de Bonito, Mato Grosso do Sul: anatomia comparada de Potamogeton gayi a. Benn. e Potamogeton illinoensis Morong, efeitos da velocidade do fluxo da água na morfologia, e o potencial de reprodução vegetativa de Potamogeton illinoensis. Dissertação de Mestrado. Universidade Federal do Mato Grosso do Sul, Campo Grande. 61p.

Roeser, K.R. 1972. Die Nadel der Schwarzklefer-Masenprodukt und Kunstwert der Natur. Mikrokosmos 61: 33-36.

Sand-Jensen, K. \& Gordon, D.M. 1984. Differential ability of marine and freshwater macrophytes to utilize $\mathrm{HCO}_{3}{ }^{-}$and $\mathrm{CO}_{2}$. Marine Biology 80 : 247-253.

Santamaría, L. 2002. Why are most aquatic plants widely distributed? Dispersal, clonal growth and small-scale heterogeneity in a stressful environment. Acta Oecologica 23: 137-154.

Santamaría, L.; Figuerola, J.; Pilon J.J.; Mjelde, M.; Green, A.J.; De Boer, T.; King, R.A. \& Gornall, R.J. 2003. 
Plant performance across latitude: role of plasticity and local adaptation in aquatic plant. Ecology 84 : 2454-2461.

Schutten, J. \& Davy, A.J. 2000. Predicting the hydraulic forces on submerged macrophytes from current velocity, biomass and morphology. Oecologia 123: 445-452.

Scremin-Dias, E.; Pott, V.J.; Hora, R.C. \& Souza, P.R. 1999. Nos jardins submersos da Bodoquena: guia para identificação de plantas aquáticas de Bonito e região. Ed. UFMS, Campo Grande. 160p.

Sculthorpe, C.D. 1967. The biology of aquatic vascular plants. St. Martins Press, New York. 610p.

Seago Jr., J.L.; Marsh, L.C.; Steves, K.J.; Soukup, A.; Votrubová, O.\& Enstone, D.E. 2005. A re-examination of the root cortex in wetland flowering plants with respect to aerenchyma. Annals of Botany 96: 565-579.

Seago Jr., J.L.; Peterson, C.A.; Kinsley, L.J. \& Broderick, J. 2000. Development and structure of the root cortex in Caltha palustris L. and Nymphaea odorata Ait. Annals of Botanty 86: 631-640.

Soukup, A.; Votrubová, O. \& Cizková, H. 2000. Internal segmentation of rhizomes of Phragmites australis: protection of the internal aeration system against being flooded. New Phytologist 145: 71-75.

Soukup, A.S.; William Armstrong, W.; Lukas Schreiber, L.; Rochus Franke, R. \& Olga Votrubová, O. 2007. Apoplastic barriers to radial oxygen loss and solute penetration: a chemical and functional comparison of the exodermis of two wetland species, Phragmites australis and Glyceria maxima. New Phytologist 173: 264-278.

Spencer, D.F. 1986. Early growth of Potamogeton pectinatus $\mathrm{L}$. in response to temperature and irradiance: morphology and pigment composition. Aquatic Botany 26: 1-8.

Van den Berg, M.; Coops, H.; Simons, J. \& Pilon, J. 2002. A comparative study of the use of inorganic carbon resources by Chara aspera and Potamogeton pectinatus. Aquatic Botany 72: 219-233.

Via, S.; Gomulkiewicz, R.; De Jong, G.; Schlichting, C.D. \& Van Tienderen, P.H. 1995. Adaptative phenotypic plasticity: consensus and controversy. Trends in Ecology \& Evolution 10: 212-217.

Wiegleb, G. 1990. The importance of stem anatomical characters for systematics of the genus Potamogeton L. Flora 184: 197-208. 